\begin{tabular}{|l|l|l|}
\hline Received : 10/05/2021 & Accepted: 20/06/2021 & Published : 30/06/2021 \\
\hline
\end{tabular}

\title{
Perancangan Prototipe Turbin Angin Sumbu Horizontal Skala Laboratorium Dengan Inverter
}

\author{
Najma Safienatin Najah ${ }^{1 *}$, Arief Muliawan ${ }^{2}$, Febria Anita ${ }^{3}$ \\ 1,2 Program Studi Teknik Mesin, Sekolah Tinggi Teknologi Industri Bontang \\ ${ }^{3}$ Program Studi Fisika, Universitas Nasional \\ 1,2 Jl Brigjend Katamso Nomor 40, Bontang, 75313 \\ *najmasafienatin@gmail.com
}

\begin{abstract}
A horizontal axis wind turbine design research has been carried out using an inverter. This study aims to generate the output power generated by the generator through an inverter. So that the use of an inverter can turn on the 10 watt lamp. From the research results obtained turbine rotation varied between $1357 \mathrm{rpm}$ to $2415 \mathrm{rpm}$ producing a generator voltage of 3.05 volts to 4.61 volts and generator currents $32 \mathrm{~mA}$ up to $49 \mathrm{~mA}$. The inverter produces a voltage of 16.57 volts up to 20.46 volts and an inverter current of 0.60 amperes up to 0.48 amperes. The greater the rotation of the wind turbine turbine, the greater the generator voltage generated and so is the voltage of the inverter. While the current will increase as the turbine rotation increases and the inverse of the inverter current will decrease as the turbine rotation increases.
\end{abstract}

Keywords: wind turbines, horizontal axis, generators, inverters

\begin{abstract}
Abstrak
Telah dilakukan penelitian perancangan turbin angin sumbu horizontal dengan menggunakan inverter. Penelitian ini bertujuan untuk membangkitkan daya keluaran yang dihasilkan oleh generator melalui inverter. Sehingga dengan penggunaan inverter dapat menghidupkan lampu 10 watt. Dari hasil penelitian diperoleh putaran turbin divariasikan antara $1357 \mathrm{rpm}$ sampai dengan $2415 \mathrm{rpm}$ menghasilkan tegangan generator sebesar 3,05 volt sampai dengan 4,61 volt dan arus generator $32 \mathrm{~mA}$ sampai dengan $49 \mathrm{~mA}$. Inverter menghasilkan tegangan 16,57 volt sampai dengan 20,46 volt dan arus inverter 0,60 ampere sampai dengan 0,48 ampere. Pada generator makin besar putaran turbin kincir angin maka makin besar pula tegangan generator yang dihasilkan dan begitu pula dengan tegangan inverter. Sedangkan arus akan naik seiring pertambahan putaran turbin dan berkebalikan pada inverter arus akan turun seiring pertambahan putaran turbin
\end{abstract}

Kata kunci: Turbin angin, sumbu horizontal, generator, inverter

\section{Pendahuluan}

Tenaga angin merupakan salah satu sumber energi terbarukan yang melimpah di negeri kita dan ramah lingkungan karena menekan emisi gas $\mathrm{CO} 2$, oleh karena itu kita dapat memperoleh listrik murah yang tidak terbatas dari energi angin. Diharapkan dengan memberikan pemahaman yang benar dan kongkrit ke mahasiswa diharapkan mereka nantinya dapat mendisain dan menciptakan sebuah pembangkit listrik tenaga angin dengan efesiensi yang baik sehingga bisa dimanfaatkan untuk kehidupan masyarakat dan mewujudkan program pemerintah untuk percepatan pemanfaatan energi terbarukan [1]. Penelitian ini merupakan penelitian pendahuluan yang dilakukan oleh STTI Bontang dalam turbin angin. Pemanfaatan energi terbarukan yang telah dilakukan seperti penggunaan turbin air telah dilakukan[2].

Pembangkit listrik tenaga angin mengkonversikan tenaga angin menjadi energi listrik dengan menggunakan kincir angin atau turbin angin. Penggunaan modifikasi lengkung sudu sangat membantu dalam unjuk kerja turbin [3]. Cara kerjanya cukup sederhana yaitu putaran turbin yang disebabkan oleh angin diteruskan ke rotor generator dimana generator ini memiliki lilitan tembaga yang berfungsi sebagai stator sehingga terjadinya GGL (gaya gerak listrik). Listrik yang dihasilkan dapat disimpan ke batrai atau dimanfaatkan langsung ke beban seperti 
lampu. Untuk membangkitkan tegangan diperlukan penambahan konverter DC-AC atau sebaliknya sesuai kebutuhan [4].

Kota Bontang selain dikenal dengan sumber daya alam yang melimpah dengan berdirinya perusahaan berkelas internasional, Kota Bontang juga memiliki potensi sumber daya perikanan dan kelautan yang dapat dilihat oleh adanya perkampungnya nelayan yang tersebar di kota Bontang. Perkampungan ini sangat membutuhkan pasokan listrik untuk kebutuhan sehari-hari baik berupa penerangan maupun aktifitas lainya. Keterbatasan PLN menyalurkan listrik ke daerah kampung nelayan ini memberikan potensi pengembangan sumber daya kelistrikan berupa tenaga surya (solar cell) dan tenaga angin.

Penggunaan teknologi alternatif pembangkit listrik tenaga bayu dapat menimalisir dampak lingkungan dan secara ekonomis cukup menguntungkan [5]. Turbin angin ini akan menangkap energi angin dan menggerakkan generator DC yang nantinya akan menghasilkan energi listrik. turbin angin yang digunakan pada penelitian ini adalah turbin angin bersudu empat buah dengan poros horizontal. Pada Turbin jenis angin atau air dapat ditingkatkan daya outputnya dengan memberikan kecepatan terhadap sudu yang dimiliki [6]. Dalam penelitian ini daya yang dihasilkan oleh generator akan dikonversikan melalui konverter sehingga daya yang dihasilkan diharapkan mampu menyalakan lampu 10 watt.

\section{Tinjauan Teori}

\section{Pehitungan daya}

Daya output turbin angin merupakan daya actual yang dihasilkan oleh pembangkit listrik tenaga angin. Untuk menghitung daya output turbin angin pada generator menggunakan persamaan sebagai berikut

$$
P=V \times I
$$

dengan

$$
\begin{aligned}
& \mathrm{P}: \text { daya generator (watt) } \\
& \mathrm{V} \text { : tegangan generator (volt) } \\
& \mathrm{I}: \text { arus generator (ampere) }
\end{aligned}
$$

Dapat dihitung torsi dari daya yang berlaku pada generator turbin angin sebagai berikut

$$
P=T \times \frac{2 \pi}{60} N
$$

dengan

$$
\begin{aligned}
& \mathrm{P}: \text { daya generator (watt) } \\
& \mathrm{T} \text { : torsi generator }(\mathrm{Nm}) \\
& \mathrm{N} \text { : putaran generator }(\mathrm{rpm})
\end{aligned}
$$

\section{Metode Penelitian}

Waktu dan Tempat Penelitian

Penelitian dilaksanakan pada bulan januari sampai dengan maret 2020. Alat dibuat di Laboratorium Teknik Mesin Sekolah Tinggi Teknologi Industri Bontang.

Bahan dan Alat Penelitan

Bahan yang dipergunakan dalam penelitian ini terdiri atas resistor $16 \mathrm{ohm}-100 \mathrm{ohm}$, kapasitor $1000 \mu \mathrm{F} 6,3 \mathrm{v}$, transistor npn tipe 41, ferrite mini transformator bekas charger hanphone, papan 
PCB, timah, lampu, kawat, generator DC dan kincir angin 4 sudu. Alat penelitian yang dipergunakan yakni solder, avo meter, tachometer dan perlengkapan lainnya

Pembuatan Alat

Pembuatan inverter dilakukan secara teliti dengan memperhatikan skema diagram berikut:

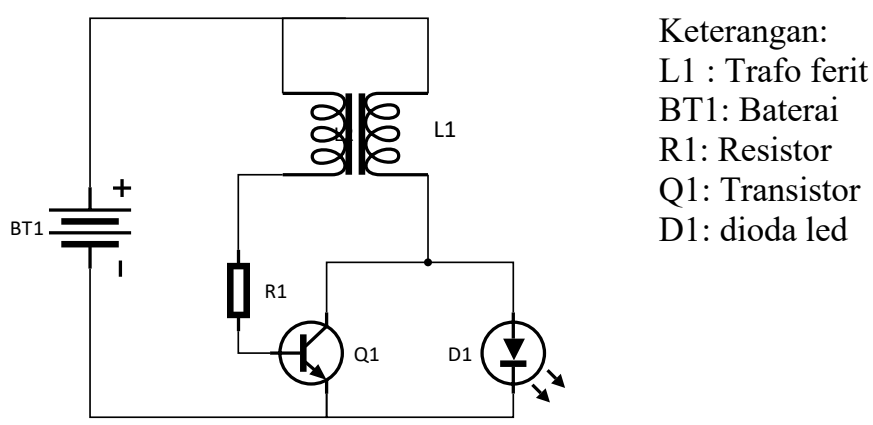

Gambar 1, Inverter peubah Energi

Pada pembuatan alat turbin angin ini dilakukan secara teliti dengan memperhatikan tahapan berikut: Kincir angin dengan bilah empat dihubungkan dengan generator, menghubungkan generator dengan kabel penghubung, setelah inverter berhasil dibuat, selanjutnya menghubungkan turbin angin dengan generator dan inverter yang dibuat.

Pengujian Alat

Jika alat yang dimaksud telah dibuat maka hal berikut yang perlu diperhatikan yakni pengujian alat dengan memperhatikan tujuan penelitian yakni mempeoleh hasil keluaran berdasarkan pengujian sumber tegangan masukan dari hasil generator.

Selanjutnya pengujian sebagai berikut:Memasang alat inverter, generator dan turbin angin.

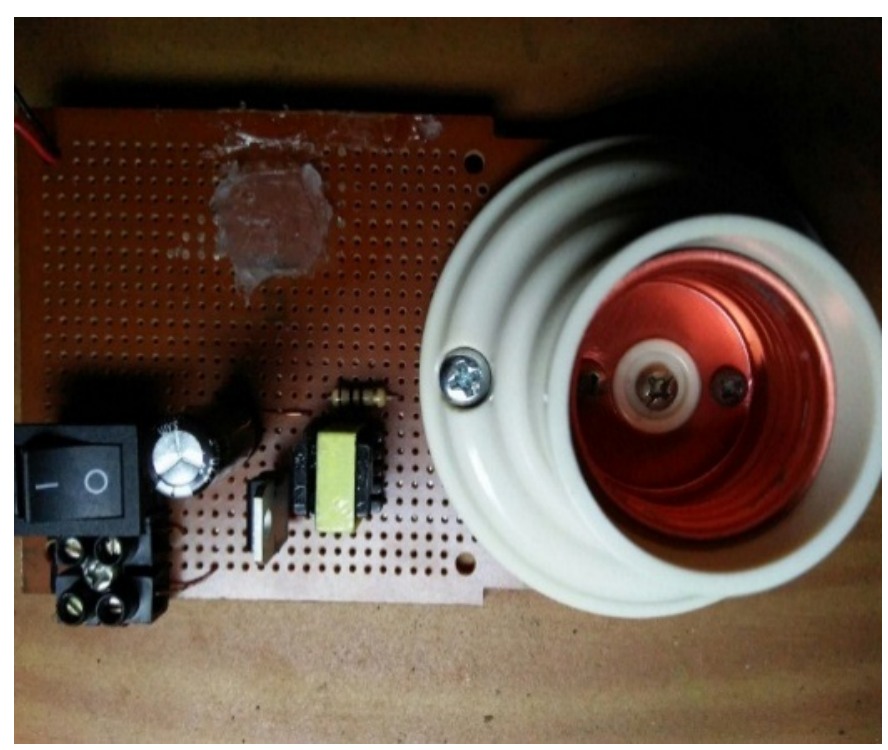

Gambar 2. Rangkaian alat

Selanjutnya dilakukan pengujian dengan putaran turbin angin yang berbeda. Pengukuran dengan menggunakan tachometer sebagai pengukur rpm putaran kincir. Mengukur hasil keluaran generator DC dengan AVO meter dengan menentukan besar tegangan keluaran, selanjutnya mengukur hasil keluaran Inverter berupa tegangan dan memberikan lampu 10 watt 
sehingga dapat mengukur arus yang melalui lampu. Selanjutnya dapat menggunakan rpm putaran kincir angin yang berbeda.

\section{Hasil dan Pembahasan}

Telah dilakukan penelitian yang dilakukan oleh peneliti yakni membuat turbin angin yang dihubungkan generator dengan inverter. Pengunaan inverter ini untuk mengubah membangkitkan tegangan DC dan menaikan tegangan kecil menjadi lebih besar sehingga dapat menaikkan beban listrik. Tegangan yang masuk ke inverter akan menyalakan beban lampu 10 watt dengan pengujian beban putaran kincir. Hasil pengujian putaran turbin terhadap keluaran tegangan ditunjukan pada tebel 1 penelitian berikut:

\begin{tabular}{cccc} 
Tabel 1. Pengambilan data tegangan variasi putaran kincir \\
\hline No & RPM & $\begin{array}{c}\text { Arus } \\
\text { generator } \\
\text { (ampere) }\end{array}$ & $\begin{array}{c}\text { Tegangan (Volt) } \\
\text { Generator }\end{array}$
\end{tabular}

\begin{tabular}{lcccc}
\hline $\mathbf{1}$ & 1357 & 0,032 & 3,05 & 16,57 \\
\hline $\mathbf{2}$ & 1589 & 0,037 & 3,73 & 17,64 \\
\hline $\mathbf{3}$ & 2017 & 0,043 & 4,24 & 18,90 \\
\hline $\mathbf{4}$ & 2415 & 0,049 & 4,61 & 20,46
\end{tabular}

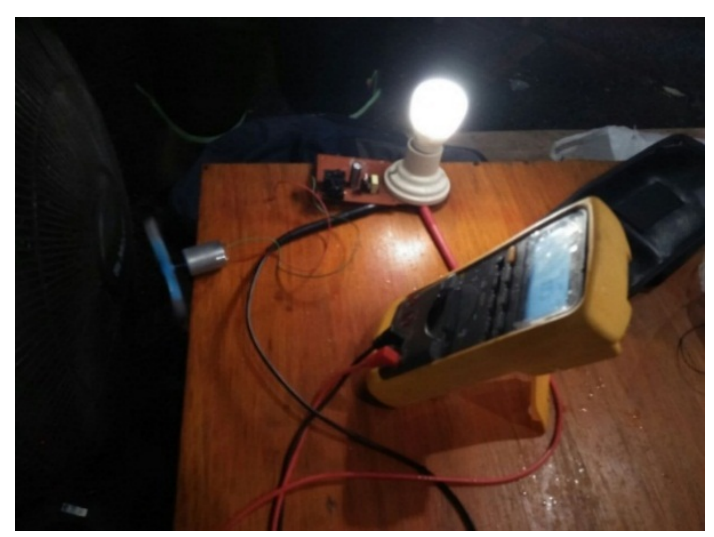

Gambar 3. Pengujian arus dan tekanan keluaran

Dari tabel 1. hasil pengukuran variasi putaran turbin terhadap tegangan keluaran turbin dan inverter ditunjukan pada gambar 4. Dari gambar 4. menunjukan bahwa makin besar putaran turbin kincir angin maka makin besar pula tegangan generator yang dihasilkan dan begitu pula dengan tegangan inverter. 


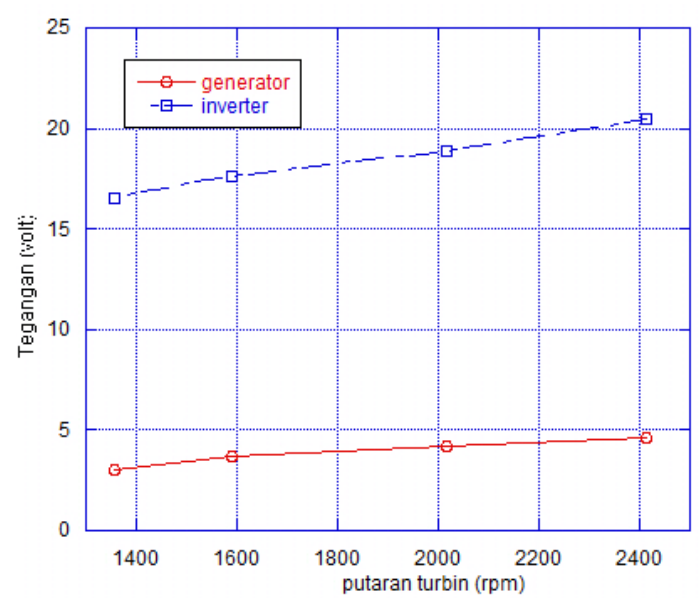

Gambar 4. Perubahan tegangan terhadap putaran turbin

Berdasarkan data pengukuran yang ditunjukan pada tabel 1 untuk perhitungan daya dapat diperoleh dengan memanfaatkan persamaan (1). Persamaan daya (1) menunjukan perkalian arus dan tegangan. Sedangkan pada persamaan (2) dilakukan perhitungan daya untuk menentukan torsi. Dengan menggunakan persamaan (1) dan (2) diperoleh hasil perhitungan

Tabel 2. Perhitungan daya dan torsi generator

\begin{tabular}{lccc}
\hline No & RPM & Daya (watt) & Torsi $(\mathrm{Nm})$ \\
\hline 1 & 1357 & 0,09760 & 0,000687 \\
2 & 1589 & 0,13801 & 0,000829 \\
3 & 2017 & 0,18232 & 0,000863 \\
4 & 2415 & 0,22589 & 0,000893 \\
\hline
\end{tabular}

Dari perhitungan daya dan torsi yang telah dilakukan kemudian ditunjukan perhitungan tersebut ditunjukan pada tabel 2, maka selanjutnya diperoleh gambaran hubungan daya generator, torsi generator terhadap putaran turbin. Berdasarkan data pengukuran yang ditunjukan pada tabel 2. untuk perhitungan arus listrik pada beban lampu 10 watt dapat diperoleh dengan memanfaatkan persamaan daya listrik. Perhitungan daya menunjukan perkalian arus dan tegangan.

Tabel 3. Perhitungan arus inverter

\begin{tabular}{lccc}
\hline \multirow{2}{*}{ No } & \multirow{2}{*}{ RPM } & \multicolumn{2}{c}{ Arus (ampere) } \\
\cline { 3 - 4 } & & Generator & Inverter \\
\hline 1 & 1357 & 0,032 & 0,6035 \\
2 & 1589 & 0,037 & 0,5669 \\
3 & 2017 & 0,043 & 0,5291 \\
4 & 2415 & 0,049 & 0,4888 \\
\hline
\end{tabular}

Dari gambar 5 menunjukan perubahan arus listrik terhadap putaran turbin. Pada generator arus akan naik seiring pertambahan putaran turbin. Sedangkan pada inverter arus akan turun seiring pertambahan putaran turbin. 


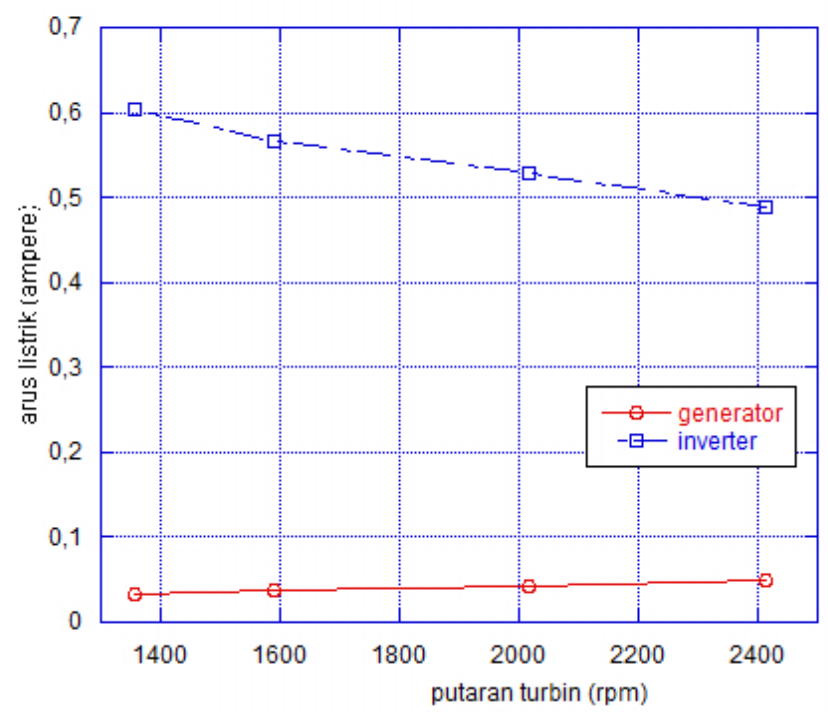

Gambar 5. Perubahan arus listrik terhadap putaran turbin

\section{Kesimpulan}

Perancangan pembangkit listrik tenaga angin sumbu horizontal dengan variasi putaran dapat menghidupkan beban lampu 10 watt. Dalam rangkaian ditambahkan inverter sebagai pembangkit tegangan. Pada generator makin besar putaran turbin kincir angin maka makin besar pula tegangan generator yang dihasilkan dan begitu pula dengan tegangan inverter. Sedangkan arus akan naik seiring pertambahan putaran turbin dan berkebalikan pada inverter arus akan turun seiring pertambahan putaran turbin.

\section{Daftar Pustaka}

[1] R. Sumiati and A. Zamri, "Rancang Bangun Miniatur Turbin Angin Pembangkit Listrik Untuk Media Pembelajaran,” Jurnal Teknik Mesin (JTM), vol. 3, no. 2, pp. 1-8, 2013.

[2] A. Yani, B. Susanto, and R. Rosmiati, "Analisis Jumlah Sudu Mangkuk Terhadap Kinerja Turbin Pelton Pada Alat Praktikum Turbin Air," Turbo: Jurnal Program Studi Teknik Mesin, vol. 7, no. 2, pp. 185-192, 2018.

[3] A. Kusbiantoro, R. Soenoko, and D. Sutikno, "Pengaruh Panjang Lengkung Sudu Terhadap Unjuk Kerja Turbin Angin Poros Vertikal Savonius.," Universitas Brawijaya Malang, 2013.

[4] S. S. Atmojo, M. Facta, and K. Karnoto, "Analisis Perancangan Konverter DC-AC Full-Bridge Frekuensi Tinggi Resonan LCC Beban Paralel," TRANSIENT, vol. 4, no. 1, pp. 200-207, 2015.

[5] I. N. Budiastra, I. D. Giriantari, W. Artawijaya, and C. I. Partha, "Pemanfaatan energi angin sebagai energi alternatif pembangkit listrik di nusa penida dan dampaknya terhadap lingkungan.," Bumi Lestari Journal of Environment, vol. 9, no. 2, pp. 263267, 2009.

[6] A. Muliawan and A. Yani, "Analisis daya dan efisiensi turbin air kinetis akibat perubahan putaran runner," Sainstek: Jurnal Sains dan Teknologi, vol. 8, no. 1, pp. 19, 2017. 